Jurnal Keperawatan Silampari

Volume 5, Nomor 1, Desember 2021

e-ISSN: 2581-1975

p-ISSN: 2597-7482

DOI: https://doi.org/10.31539/jks.v5i1.2845

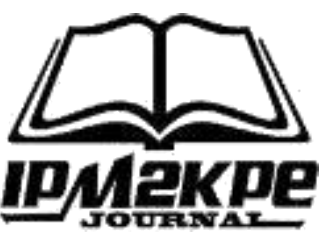

\title{
KREATIVITAS TERHADAP MINAT BERWIRAUSAHA MAHASISWA KEPERAWATAN
}

\author{
Ernawati \\ Sekolah Tinggi Ilmu Kesehatan Hang Tuah Tanjungpinang \\ Erna47522@gmail.com
}

\begin{abstract}
ABSTRAK
Penelitian ini bertujuan untuk mengetahui pengaruh kreativitas terhadap minat berwirausaha mahasiswa Stikes Hang Tuah Tanjungpinang. Metode yang digunakan dalam penelitian ini adalah metode penelitian kuantitatif dengan pendekatan asosiatif kausal. Hasil penelitian ini menunjukkan bahwa sebagian besar responden berjenis kelamin perempuan yaitu sebanyak 84 mahasiswa (75\%). Sebagian besar responden berusia 18-20 tahun yaitu sebanyak 102 mahasiswa (91.1\%). Analisis bivariat menunjukkan bahwa kretativitas dan minat berwirausaha diperoleh nilai $t$ hitung besar dari t tabel $(10.702>1,658)$ dengan nilai p $0,000<0,05$. Simpulan, kreativitas berpengaruh positif dan signifikan terhadap minat berwirausaha mahasiswa di Stikes Hang Tuah Tanjungpinang.
\end{abstract}

Kata Kunci: Kreativitas, Minat Berwirausaha

\section{ABSTRACT}

This study aims to determine the effect of creativity on the entrepreneurial interest of Stikes Hang Tuah Tanjungpinang students. The method used in this study is a quantitative research method with a causal associative approach. The results of this study indicate that most of the respondents are female, as many as 84 students (75\%). Most of the respondents aged 18-20 years were 102 students (91.1\%). Bivariate analysis showed that creativity and interest in entrepreneurship obtained a large t-count value from the t-table $(10,702>1.658)$ with a p-value of $0.000<0.05$. In conclusion, invention has a positive and significant effect on student entrepreneurship interest at Stikes Hang Tuah Tanjungpinang.

Keywords: Creativity, Interest in Entrepreneurship

\section{PENDAHULUAN}

Profesi keperawatan dipandang sebagai pribadi yang diteladani menjadi pelayan yang lebih identik dengan model kerja pegawai. Terlepas dari kekhususan pekerjaannya, seorang perawat telah dianggap sebagai seorang profesional yang dibentuk untuk bekerja di institusi yang bergerak di bidang pelayanan kesehatan, baik di luar negeri maupun di dalam negeri. Sehingga perawat seolah-olah hanya mampu bekerja sebagai pemberi asuhan keperawatan di rumah, rumah sakit, klinik, puskesmas atau lembaga pelatihan keperawatan yang tentunya identik dengan gaji atau gaji bulanan. Salah satu hal hebat yang tidak boleh diabaikan oleh seorang perawat adalah menjadi seorang wirausaha atau entrepreneur (Indarwati et al., 2020). 
Seorang perawat bisa menjadi nurse entrepreneur atau nurse intrapreneur. erawat wirausaha adalah perawat yang menjalankan bisnisnya sendiri atau dengan beberapa teman di industri keperawatan. Sedangkan nurse intrapreneur adalah perawat yang menjalankan usaha pada divisi atau bagian dari usaha yang sudah ada (Puspita et al., 2021). Luasnya dimensi pelayanan keperawatan dalam profesi kesehatan hendaknya dijadikan sebagai peluang bagi perawat untuk membangun budaya entrepreneurship, baik berupa barang maupun jasa. Tumbuhnya minat perawat dalam berwirausaha diharapkan dapat menciptakan persepsi baru bahwa keperawatan merupakan profesi yang sangat menjanjikan yang dapat memberikan citra positif bagi profesi keperawatan, dimulai dengan meningkatnya status ekonomi perawat.

Menumbuhkan jiwa entrepreneurship bagi perawat sangat penting karena banyak hal yang dapat dilakukan perawat dalam memilih wirausaha, seperti membuka klinik kesehatan atau klinik keperawatan yang dapat membuka lapangan kerja bagi orang lain (Hidayati et al., 2018). Perawat entrepreneurship dapat membangun jenis usaha homecare dan guest house. Selain itu, perawat juga bisa berbisnis dalam bidang catering, misalnya catering yang menyediakan makanan bagi pasien penderita hipertensi.

Ginting (2020) mengatakan minat berwirausaha akan menjadikan seseorang lebih giat mencari dan memanfaatkan peluang usaha dengan mengoptimalkan potensi yang dimiliki. Minat berwirausaha merupakan keinginan, ketertarikan, serta kesediaan individu untuk bekerja keras dalam memenuhi kebutuhan hidupnya tanpa takut dengan resiko yang akan terjadi. Seorang nurse entrepreneur memiliki enam komponen penting yaitu, percaya diri, berorientasi pada hasil, berani mengambil resiko, kepemimpinan, keorisinalitasan dan berorientasi pada masa depan.

Wirausaha adalah seseorang yang memiliki keterampilan menjual, mulai dari menawarkan ide hingga barang berupa produk atau jasa (Rohmah \& Widya, 2020)(Santi. Rohmah \& Widya, 2020). Dengan kreativitasnya, wirausahawan mampu beradaptasi dengan situasi dan kondisi lingkungan yang berbeda. Sebagai pebisnis, wirausahawan perlu mengenal manajemen penjualan, gaya manajemen, dan fungsi. Selain itu, pengusaha juga harus mampu berkomunikasi dan menguasai berbagai elemen keterampilan manajerial, serta mengetahui teknik penjualan strategis mulai dari pengetahuan produk, karakteristik produk dan daya saing produk dibandingkan dengan produk sejenis.

Perawat yang mampu melihat dan mengevaluasi peluang bisnis terkait profesinya yang merupakan bagian integral dari pelayanan kesehatan dengan tetap memperhatikan pelayanan profesional adalah perawat yang memiliki jiwa wirausaha (Rohmah \& Widya, 2020).

Salah satu cara untuk menghadirkan minat berwirausaha adalah menumbuhkan kreativitas berwirausaha (Fajar et al., 2020). Kreativitas adalah inisiatif terhadap suatu produk atau proses yang bermanfaat, benar, tepat, dan bernilai terhadap suatu tugas yang lebih bersifat heuristic yaitu sesuatu yang merupakan pedoman, petunjuk, atau panduan yang tidak lengkap yang akan menuntun kita untuk mengerti, mempelajari, atau menemukan sesuatu yang baru.

Penelitian Aprillia (2020) menunjukkan bahwa kreativitas, motivasi, dan sifat kepribadian berpengaruh signifikan terhadap minat berwirausaha. Kreativitas adalah sumber daya penting untuk menciptakan daya saing bagi semua organisasi yang peduli dengan pertumbuhan dan perubahan. Pengetahuan kewirausahaan juga dapat diperoleh dengan bertukar pikiran dengan pengusaha lain. Kegiatan diskusi yang juga dilakukan oleh pengusaha dapat membuka ide dan inovasi pada bisnis yang akan dikelola. 
Mahasiswa yang tertarik untuk membuka usaha baru akan sering bertanya dan belajar tentang bisnis dengan orang lain yang sudah membuka usaha terlebih dahulu. Dengan cara ini, pengetahuan kewirausahaan didasarkan pada materi yang disajikan oleh fakultas dari universitas dan diskusi dengan pengusaha untuk membuka ide untuk bisnis.

Berdasarkan hasil observasi yang dilakukan di STIKES Hang Tuah Tanjungpinang, menunjukkan bahwa perkembangan kemajuan teknologi, banyak mahasiswa yang menggunakan media sosial seperti Facebook, Instagram dan lain-lain sebagai sarana mempromosikan barang yang mereka jual. Hal ini sejalan dengan penelitian sebelumnya yang menyatakan bahwa motivasi, kreativitas, dan inovasi merupakan salah satu faktor yang mempengaruhi minat berwirausaha. Oleh karena itu, dalam penelitian ini peneliti menyelidiki pengaruh kreativitas terhadap minat berwirausaha mahasiswa Stikes Hang Tuah Tanjungpinang. Hal ini penting karena akan meningkatkan minat mahasiswa untuk berwirausaha. Selain itu, penelitian ini masih jarang dilakukan bahkan di tempa penelitian belum pernah dilakukan.

\section{METODE PENELITIAN}

Metode yang digunakan adalah investigasi kuantitatif yang diuji dengan perhitungan statistik menggunakan program SPSS. Partisipan dalam penelitian ini adalah seluruh mahasiswa sarjana (S1) dan Diploma 3 (D3) keperawatan yang mengambil mata kuliah Kewirausahaan Ilmu Keperawatan, jumlah mahasiswa STIKES Hang Tuah Tanjungpinang sebanyak 112 orang.

Populasi dalam penelitian ini terdiri dari 121 orang dan proses pengembalian angket hanya 112 siswa, sehingga penelitian ini akan menggunakan metode sensus yaitu seluruh populasi akan diteliti. Penelitian ini menggunakan SPSS 24 dalam pengolahan datanya dengan terlebih dahulu melakukan uji validitas dan uji reliabilitas, dilanjutkan dengan uji asumsi klasik meliputi uji normalitas, uji multikolinearitas, uji heteroskedastisitas, dan uji autokorelasi, kemudian menggunakan analisis regresi linier sederhana untuk menjawab uji hipotesis.

\section{HASIL PENELITIAN}

Deskripsi Karakteristik Responden

Tabel. 1

Distribusi Frekuensi Berdasarkan Karakteristik Responden

\begin{tabular}{ccc}
\hline Jenis Kelamin & $\mathrm{N}$ & $\%$ \\
\hline Laki-laki & 28 & $25 \%$ \\
Perempuan & 84 & $75 \%$ \\
Usia & & \\
18-20 Tahun & 102 & 91,1 \\
21-23 Tahun & 10 & 8,9 \\
Total & 112 & $100 \%$ \\
\hline
\end{tabular}

Berdasarkan tabel 1 menunjukkan bahwa sebagian besar responden berjenis kelamin perempuan yaitu sebanyak 84 mahasiswa (75\%). Sebagian besar responden berusia 18-20 tahun yaitu sebanyak 102 mahasiswa (91.1\%). 


\section{Uji Hipotesis}

Tabel. 2

Uji Hipotesis Coefficients ${ }^{\mathrm{a}}$

\begin{tabular}{|c|c|c|c|c|c|c|}
\hline & \multirow[t]{2}{*}{ Model } & \multicolumn{2}{|c|}{$\begin{array}{l}\text { Unstandardized } \\
\text { Coefficients }\end{array}$} & \multirow{2}{*}{$\begin{array}{c}\text { Standardized } \\
\text { Coeefficients } \\
\text { Beta } \\
\end{array}$} & \multirow[b]{2}{*}{$\mathrm{t}$} & \multirow[b]{2}{*}{ Sig. } \\
\hline & & $\mathrm{B}$ & Std. Error & & & \\
\hline 1 & (Constant) & 8.137 & 1.600 & & 5.086 & .000 \\
\hline & Total_X & .740 & .069 & .714 & 10.702 & .000 \\
\hline
\end{tabular}

Berdasarkan tabel 2 menunjukkan bahwa variabel kreativitas nilai sig 0,000 dan nilai t hitung 10.702. Ini berarti nilai sig lebih kecil dari taraf signifikansi $0,05(<0,05)$ sehingga Kreativitas berpengaruh terhadap minat berwirausaha.

Angka $\mathrm{R}$ disebut koefisien korelasi antara variabel kreativitas dengan minat berwirausaha adalah 0,714. Ini artinya hubungan antara kreativitas dengan minat Berwirausaha adalah kuat (signifikan) sebesar 77.5\%. Adjusted R2 dalam penelitian ini bernilai 0,510 , hal ini menujukkan bahwa sebesar $51 \%$ minat berwirausaha pada mahasiswa STIKES Hang Tuah Tanjungpinang dipengaruhi oleh kreativitas. Sedangkan sisanya sebesar $49 \%$ dipengaruhi atau dijelaskan oleh faktor-faktor lain yang tidak dimasukkan dalam penelitian ini.

\section{PEMBAHASAN}

\section{Pengaruh Kreativitas terhadap Minat Berwirausaha Mahasiswa STIKES Hang Tuah Tanjungpinang}

Hasil penelitian menjelaskan bahwa kreativitas mempengaruhi minat mahasiswa keperawatan untuk berwirausaha. Dengan kata lain, jika siswa sangat kreatif, mereka akan memiliki tingkat minat berwirausaha yang tinggi. Sebaliknya, siswa dengan sedikit kreativitas memiliki sedikit minat dalam berwirausaha. Hasil penelitian ini sejalan dengan penelitian Aprillia (2020) yang mengemukakan bahwa kreativitas mempengaruhi minat berwirausaha. Kreatif dan inovatif menjadi dasar, nasehat dan sumber untuk mencari peluang sukses.

Dalam mengelola perusahaan, keberhasilan seorang wirausahawan terletak pada sikap dan kemampuan berbisnis serta memiliki etos kerja yang tinggi. Semangat kerja atau etos kerja yang tinggi dari seorang wirausahawan terletak pada kreativitas dan kepercayaan diri untuk memajukan wirausaha. Seorang wirausahawan kreatif dapat menciptakan hal-hal baru untuk menumbuhkan bisnis. Berpikir kreatif berhubungan langsung dengan penciptaan nilai, penciptaan nilai dan pencarian peluang bisnis (Ginting, 2020).

Selain itu, Fajar et al., (2020) juga mengatakan bahwa semakin kreatif mahasiswa dalam mencipta, memodifikasi dan menggabungkan hal-hal yang diterimanya maka semakin kreatif pula potensi minat mahasiswa untuk berwirausaha. Demikian juga minat berwirausaha dalam berbagai kegiatan akan meningkat. Terhubung dengan kegiatan ini akan lebih merangsang minat berwirausaha.

Kata kewirausahaan keperawatan mencakup pemahaman tentang keterampilan sosial yang dimiliki perawat untuk mengubah tantangan dan hambatan menjadi keuntungan. Artinya diperlukan keterampilan kewirausahaan berupa kreativitas (Mustaqim, 2017). Perawat merupakan profesi kesehatan yang saat ini memegang peranan utama dalam penyelenggaraan pelayanan kesehatan di Indonesia. Namun tidak dapat dipungkiri bahwa 
kesejahteraan seorang caregiver sangat penting agar pelayanan keperawatan klien dapat berhasil secara optimal. Di sisi lain, profesi lain di luar bidang keperawatan berkembang pesat, seperti kedokteran, kesehatan masyarakat, dan lain-lain.

Saat ini, upaya transfer perawat ke luar negeri menjadi alternatif utama untuk meningkatkan kesejahteraan perawat, termasuk kewirausahaan (Aidha, 2017). Perawat yang giat tidak melupakan layanan perawatan pasien. Pelayanan kesehatan kepada pasien merupakan tujuan utama menurut standar keperawatan. Karena asuhan merupakan pelayanan profesional yang merupakan bagian integral dari sistem kesehatan, berupa pelayanan biopsikososial-spiritual yang menyeluruh bagi orang, keluarga, dan masyarakat, baik sakit maupun sehat, yang meliputi seluruh proses kehidupan manusia.

Kewirausahaan adalah kegiatan yang tidak dibatasi oleh ruang dan waktu; Lokasi, usia, jenis kelamin, dll, selama orang yang ingin menjadi pengusaha mampu memanfaatkan setiap peluang yang datang dengan lebih produktif. Jika anda ingin menjadi seorang pengusaha, anda tidak perlu menunggu lama atau membiarkan isu gender dan alasan lainnya menahan anda, selama ANDA memiliki kemampuan, kemauan, dan keberanian untuk menjadi seorang pengusaha.

Kewirausahaan muncul ketika seseorang berani mengembangkan usaha dan ide barunya. Proses bisnis mencakup semua fungsi, aktivitas, dan tindakan yang terkait dengan memperoleh peluang dan mendirikan organisasi bisnis. Oleh karena itu, wirausahawan adalah orang yang memanfaatkan peluang dan menciptakan organisasi untuk memanfaatkan peluang tersebut. Peran mereka adalah untuk memperkenalkan produk baru, menerapkan metode produk baru, memasuki pasar baru, mengembangkan bahan/sumber baru, dan mengimplementasikan organisasi baru.

Seorang perawat dapat menjadi nurse entrepeneur dengan menjalankan bisnisnya sendiri atau dalam bisnis keperawatan dengan beberapa teman (Maransika et al., 2019). Tentu ini berbeda dengan apa yang dilakukan perawat pada umumnya, dan Anda tidak bekerja di rumah sakit, yang tentu saja bukan "tempat kerja". Perawat enterprise dapat diartikan sebagai perawat yang memiliki jiwa wirausaha dengan tingkat kreativitas, keberanian, dan inisiatif yang tinggi. Perawat yang melakukan praktik keperawatan pra praktik memiliki banyak keunggulan (Noyumala, 2020). Seorang nursepreneurship memiliki jam kerja yang fleksibel, kemampuan mengelola aktivitas sendiri, kemampuan meningkatkan posisi keuangan, dan kemampuan menciptakan lapangan kerja, sehingga peluang untuk berwirausaha perawat semakin banyak.

\section{SIMPULAN}

Kreativitas berpengaruh positif dan signifikan terhadap minat berwirausaha mahasiswa keperawatan di STIKES Hang Tuah Tanjungpinang. Variabel kreativitas mempengaruhi minat berwirausaha mahasiswa sebesar 51\%, sedangkan $49 \%$ lainnya dipengaruhi oleh variabel lain yang tidak di teliti dalam penelitian ini.

\section{SARAN}

Diharapkan kepada mahasiswa untuk terus meningkatkan kreativitas dalam membentuk dan meningkatkan minat berwirausaha.

Diharapkan kepada dosen dan seluruh tendik untuk diadakannya peran kreativitas mahasiswa setiap tahunnya untuk melihat produk-produk kreativitas yang dibuat oleh mahasiswa. Selain itu juga dapat dilakukan pemberian dana untuk mahasiswa STIKES Hang Tuah Tanjungpinang guna mambuat usaha yang inovatif agar mahasiswa terbiasa 
terjun ke lapangan dalam berkreativitas untuk melakukan berwirausaha yang bermakna luas.

Diharapkan bagi peneliti selanjutnya, diharapkan dapat menambah variabel-variabel penelitian lain. Hal ini dilakukan untuk memperoleh hasil yang lebih akurat dan menunjukkan apakah penelitian dengan menggunakan sampel dan variabel yang lebih bervariasi dapat memberikan hasil yang berbeda atau sama.

\section{DAFTAR PUSTAKA}

Aidha, Z. (2017). Pengaruh Motivasi terhadap Minat Berwirausaha Mahasiswa Fakultas Kesehatan Masyarakat Universitas Islam Negeri Sumatera Utara. Jumantik, 1(1), 42-59. http://jurnal.uinsu.ac.id/index.php/kesmas/article/view/1015

Aprillia, H. (2020). Pengaruh Kreativitas, Motivasi dan Sifat Kepribadian Minat Berwirausaha pada Mahasiswa Fakultas Ekonomi dan Bisnis Universitas Tarumanagara. Universitas Tarumanagara Jakarta. http://repository.untar.ac.id/30268/

Fajar, A., Syam, A., Rakib, M., \& Tahir, T. (2020). Pengaruh Pengetahuan dan Kreativitas Kewirausahaan terhadap Minat Berwirusaha Mahasiswa Pendidikan Ekonomi Fakultas Ekonomi Universitas Negeri Makssar. Indinesian Journal of Social and Educational Studies, 1(2), 34-43. https://ojs.unm.ac.id/ijses/article/view/17460

Ginting, D. S. (2020). Mengembangkan Kompetensi Entrepreneur Kepada Perawat. Universitas Sumatera Utara. https://osf.io/vypxc/

Hidayati, E., Nugroho, H. A., \& Indrawati, N. D. (2018). Pelatihan Pijat Dewasa pada Mahasiswa Fakultas Ilmu Keperawatan dan Kesehatan Sebagai Bekal Berwirausaha. Prosiding Seminar Nasional Unimus, 1, 42-46. https://prosiding.unimus.ac.id/index.php/semnas/article/view/24

Indarwati, R., Efendi, F., Wahyuni, S. D., \& Susanti, I. A. (2020). Aplikasi Pasar Kerja Perawat Sebagai Upaya Pendayagunaan Perawat Indonesia. PEDULI: Jurnal Ilmiah Pengabdian Pada Masyarakat, 4(2), 1-9. https://doi.org/10.37303/peduli.v4i2.181

Maransika, A. A. I., Putri, N., Ayu, P., M., Diah, P., \& Dewi, S. (2019). Kewirausahaan Strategi Kewirausahaan dalam Bidang Keperawatan/Kesehatan. Politeknik Kesehatan Denpasar. https://pdfcoffee.com/strategi-kewirausahaan-1docx-pdffree.html

Mustaqim, Y. (2017). Spiritual Entrepreneurship dalam Jiwa Perawat. Indonesia Jurnal Perawat, 2(2), 63-68. https://docplayer.info/116142556-Spiritual-entrepreneurshipdalam-jiwa-perawat.html

Noyumala. (2020). Persepsi Mahasiswa Program Studi Ilmu Keperawatan STIKES Gunung Sari terhadap Kewirausahaan dalam Keperawatan. Jurnal Kesehatan, XIII(2). https://ojs.stikes.gunungsari.id/index.php/JBK/article/view/41

Puspita, A. P. W., Castury, D., Suparto, T. A., \& Hermayanti, Y. (2021). Nursing Entrepreneurship Development: Literature Review. Indonesian Journal of Cummunity Development, $1(1), \quad 8-18$. https://ejournal.upi.edu/index.php/IJCD/article/view/33157/14252

Rohmah, S, \& Widya, M. A. S. (2020). Analisis Pengaruh Pendidikan Kewirausahaan dan Kecerdasan terhadap Intensi Berwirausaha Mahasiswa. Jurnal Inovasi Pendididkan Ekonomi, 10(2), 178-182. https://doi.org/10.24036/011094710 